\title{
NR5A1 wt Allele
}

National Cancer Institute

\section{Source}

National Cancer Institute. NR5A1 wt Allele. NCI Thesaurus. Code C75871.

Human NR5A1 wild-type allele is located in the vicinity of $9 q 33$ and is approximately $26 \mathrm{~kb}$ in length. This allele, which encodes steroidogenic factor 1 protein, is involved in the activation of transcription for genes that are associated with steroid processing. Mutations in the gene are a factor in both XY sex reversal with or without adrenal failure and adrenocortical insufficiency without ovarian defect. 